\title{
Sonoelastographic evaluation of the distal femoral cartilage in patients with anterior cruciate ligament reconstruction
}

\author{
Ön çapraz bağ tamiri yapılan hastalarda distal femoral kıkırdağın \\ sonoelastografik değerlendirmesi
}

\author{
Semih Akkaya, MD., ${ }^{1}$ Nuray Akkaya, MD., ${ }^{2}$ Harun R Güngör, MD., ${ }^{1}$ Kadir Ağladıoğlu, MD., ${ }^{3}$ \\ Nusret Ök, MD., Levent Özçakar, MD. ${ }^{4}$

\begin{abstract}
'Department of Orthopedics and Traumatology, Medical Faculty of Pamukkale University, Denizli, Turkey ${ }^{3}$ Department of Radiology, Medical Faculty of Pamukkale University, Denizli, Turkey

${ }^{4}$ Department of Physical Medicine and Rehabilitation, Medical Faculty of Hacettepe University, Ankara, Turkey
\end{abstract} \\ ${ }^{2}$ Department of Physical Medicine and Rehabilitation, Medical Faculty of Pamukkale University, Denizli, Turkey
}

\begin{abstract}
Objectives: This study aims to evaluate sonoelastographic properties of the distal femoral cartilage in patients with anterior cruciate ligament (ACL) reconstruction.

Patients and methods: Demographic characteristics and operative data of 28 patients ( 27 males, 1 female; mean age $31.7 \pm 7.1$ years; range 22 to 48 years) with unilateral ACL reconstruction were evaluated. Reconstruction was performed with patellar tendon graft in 22 patients (78.6\%) and hamstring tendon graft in six patients (21.4\%). Lysholm knee score was used for functional evaluation and chair stand test was used for lower extremity strength. Medial, intercondylar, and lateral distal femoral cartilage thicknesses of operated knees and healthy knees were measured with B-mode ultrasound, while strain ratios were measured with real time sonoelastography.
\end{abstract}

Results: Postoperative mean follow-up duration was $20.4 \pm 9.8$ months. Mean Lysholm knee and patient satisfaction scores were $88.0 \pm 8.5$ and $8.2 \pm 1.8$, respectively. Cartilage thicknesses were similar between operated and healthy knees (all $\mathrm{p}>0.05$ ). Sonoelastographic strain ratio of medial distal femoral cartilage in operated knees was significantly higher (softer cartilage) $(\mathrm{p}=0.026)$. There was a negative correlation between strain ratio difference of medial cartilage of operated knees and lower extremity muscle strength $(\mathrm{p}=0.009, \mathrm{r}=-0.487)$.

Conclusion: While there was no difference for cartilage thickness between operated and healthy knees in B-mode ultrasound evaluation, detection of sonoelastographic strain ratio changes in medial distal femoral cartilage on the operated sides may indicate early structural changes following ACL reconstruction. Further studies are required to highlight the clinical effects of this relationship between the changes in cartilage structure and sonoelastography features.

Keywords: Anterior cruciate ligament; distal femoral cartilage; elastography; strain ratio; ultrasound.
ÖZ

Amaç: Bu çalışmada ön çapraz bağ (ÖÇB) tamiri yapılan hastalarda distal femoral kıkırdağın sonoelastografik özellikleri değerlendirildi.

Hastalar ve yöntemler: Tek taraflı ÖÇB tamiri yapılan 28 hastanın (27 erkek, 1 kadın, ort. yaş $31.7 \pm 7.1$ yıl; dağılım 22-48 y1l) demografik özellikleri ve ameliyat verileri değerlendirildi. Yirmi iki hastada (\%78.6) patellar tendon grefti ve altı hastada (\%21.4) hamstring tendon grefti ile tamir uygulandı. Fonksiyonel değerlendirme için Lysholm diz skoru ve alt ekstremite gücü için sandalyeye oturma kalkma testi kullanıldı. Ameliyat edilen dizler ve sağlıklı dizlerde medial, interkondiler ve lateral distal femoral kıkırdak kalınlıkları B-mod ultrasonografi, gerilim oranları ise gerçek zamanlı sonoelastografi ile ölçüldü.

Bulgular: Ameliyat sonrası ortalama takip süresi $20.4 \pm 9.8$ ay idi. Ortalama Lysholm diz ve hasta memnuniyeti skorları sırasıyla $88.0 \pm 8.5$ ve $8.2 \pm 1.8$ idi. Kıkırdak kalınlıkları ameliyatlı ve sağlıklı dizler arasında benzerdi (tamamı p>0.05). Ameliyatlı dizlerde medial distal femoral kıkırdağın sonoelastografik gerilim oranı anlamlı olarak yüksek idi (daha yumuşak kıkırdak) ( $\mathrm{p}=0.026)$. Ameliyatlı dizlerde medial kıkırdak gerilim oranı farklılığ ekstremite kas gücü arasında negatif korelasyon vardı $(\mathrm{p}=0.009$, $\mathrm{r}=-0.487)$.

Sonuç: B-mod ultrasonografi ile değerlendirildiğinde ameliyatlı ve sağlıklı dizler arasında kıkırdak kalınlığı açısından farklılık olmasa da ameliyatlı taraflarda medial distal femoral kıkırdakta sonoelastografik gerilim oranı değişikliklerinin saptanması ÖÇB tamirini takiben erken yapısal değişikliklere işaret ediyor olabilir. Kıkırdak yapısındaki değişiklikler ile sonoelastografi özellikleri arasındaki bu ilişkinin klinik etkilerinin açığa çıkarılması için ileri çalışmalara ihtiyaç vardır.

Anahtar sözcükler: Ön çapraz bağ; distal femoral kıkırdak; elastografi; gerilim oranı; ultrason.

- Received: October 28, 2015 Accepted: December 03, 2015

- Correspondence: Nuray Akkaya, MD. Pamukkale Üniversitesi Tip Fakültesi Fiziksel Tıp ve Rehabilitasyon Anabilim Dall, 20070 Kınıkl, Denizli, Turkey. Tel: +90 536- 8204501 Fax: +90 258-211 8129 e-mail: nrakkaya@gmail.com 
Increased risk of degenerative knee osteoarthritis (OA) due to mechanical instability following anterior cruciate ligament (ACL) injury has been reported in experimental and clinical studies. ${ }^{[1-4]}$ Therefore, either by using bone-patellar tendon-bone (ВРТВ) or hamstring auto-grafts, ACL reconstruction is generally recommended in mid-substance injuries that are not expected to heal after injury. ${ }^{[5]}$ Primary goals of ACL reconstruction in this group of patients are maintenance of knee stability and achievement of pre-injury activity levels. ${ }^{[6]}$

Although satisfactory short- and mid-term followup results have been reported in the literature, the effects of ACL reconstruction surgery on early degenerative changes of knee articular cartilage is contradictory. ${ }^{[1,7-10]}$ While some long-term studies (with a mean follow-up of 8.8 years) report no difference of articular cartilage and meniscal degeneration between operated and non-operated knees, ${ }^{[10]}$ other studies report increased risk of knee degeneration if there is accompanying cartilage injury or if menisectomy is also performed during ACL reconstruction. ${ }^{[6]}$

Thickness measurement and echogenicity evaluation of distal femoral cartilage by gray scale ultrasound (US) has been reported previously. ${ }^{[11,2]}$ Cartilage thinning is a known entity in the case of knee osteoarthritis. However, there is some debate regarding the assessment of cartilage thickness with B-mod US in knee osteoarthritis due to the report of swelling in fibrillated cartilage with superficial lesions especially in early grades of cartilage degeneration before the significant cartilage loss. ${ }^{[11-13]}$ Sonoelastography is a relatively new US technique to evaluate the tissue structure by the assessment of tissue elasticity. ${ }^{[14]}$ During sonoelastography, tissue compression results in a strain (shift) which is lower in hard tissues than in soft tissues. ${ }^{[15]}$ In a recent study, it has been reported that healthy and pathologic cartilages can be differentiated by measuring strain ratios using real-time sonoelastography. ${ }^{[16]}$ Since the results of studies reporting the effects of ACL reconstruction on cartilage degenerative changes were contradictory, ${ }^{[1,7-10]}$ there is still a need for a cartilage structure-screening tool in ACL reconstructed patients. We hypothesized that sonoelastography may be a useful method to detect the early changes in cartilage tissue stiffness after ACL reconstruction. Accordingly, in this study, we aimed to evaluate sonoelastographic properties of the distal femoral cartilage in patients with $\mathrm{ACL}$ reconstruction.

\section{PATIENTS AND METHODS}

A retrospective analysis was performed to determine patients who had undergone ACL reconstruction (either with BPTB or hamstring auto-graft) with the same arthroscopic single bundle technique by the same orthopedic surgeon and the same standardized rehabilitation protocol between January 2008 and June 2014 in Pamukkale University. Twenty-eight patients (27 males, 1 female; mean age 31.7 \pm 7.1 years; range 22 to 48 years) were included in the study. A written informed consent was obtained from each patient. Ethical committee approval was obtained from the Local Ethical Committee of Pamukkale University Medical Faculty. The study was conducted in accordance with the principles of the Declaration of Helsinki.

Exclusion criteria were the presence of any of the following; inflammatory or septic arthritis history in the operated knee, additional meniscal procedure in the ipsilateral knee, history of operation, trauma or ligamentous injury in the contralateral knee, restriction of knee range of motion (ROM), history of fracture or osteochondral lesion in the knees, more than one operation in the same knee, history of operation or arthritis in the hips, history of arthroplasty or similar operations in any lower limb joint, multiple trauma, or mechanical axis deviation in any lower limb.

Demographic and clinical characteristics of the subjects, i.e. age, weight, height, body mass index (BMI- $\left.\mathrm{kg} / \mathrm{m}^{2}\right)$, site of operated knee, duration of symptoms before the operation (months), postoperative follow-up period (months), type of the graft used (BPTB or hamstring) and accompanying cartilage or meniscal lesions, were recorded from operation records.

Knee pain severity $(0=$ no pain, $10=$ worst pain $)$ and postoperative satisfaction status $(0=$ worst, $10=$ best $)$ of the patients were evaluated by visual analog scale. Lysholm knee scoring system was used to evaluate functional status of the patients. ${ }^{[17]}$

Chair stand test was evaluated to assess the lower limb strength. A standard chair with arms and a seat height of approximately $43 \mathrm{~cm}$ was used. Patients were asked to sit in the chair, cross their arms against their chests, keep their backs straight and feet flat on floor, and sit-stand as many as possible during a 30 second period, and the scores were recorded. ${ }^{[18]}$

Ultrasound examinations were performed using a 2.5-13 MHz linear probe (Logiq E9, GE Medical Systems, Wauwatosa, WI, USA). Subjects lied supine on the examination table with maximum knee flexion $\left(>125^{\circ}\right) \cdot{ }^{[11]}$ During axial imaging, cartilage thicknesses 
were measured from the midpoints of medial condyle, intercondylar area, and the lateral condyle by drawing a vertical line between cartilage-bone and synovial space-cartilage surfaces. ${ }^{[12]}$ Mean values of three successive measurements for each site were noted.

During sonoelastography, the US probe was placed on the distal femoral cartilage of the examined knee while subjects were kept in the same position as described above. Compression with slight vibrating motions (rhythmic compression and relaxation cycles) was applied to acquire appropriate images. Color scale was evaluated on the US monitor (at least five green columns were obtained out of seven) to maintain the relevance and the standardization of the applied compression. Color-coded real time images were recorded on B-mode screen and the machine's software coded colors in a scale of 1 (red; soft) to 6 (blue; hard) (Figure 1). Three recorded US images were chosen randomly and circular areas (region of interest) were marked on the reference (subcutaneous) tissue and the three cartilage regions (midpoints of medial condyle, intercondylar area, and lateral condyle). The machine's software calculated the strain ratios (reference tissue strain/cartilage strain) of each region. In relation with this calculation, increase of strain ratio means softening of cartilage tissue compared to reference tissue. Mean values of three successive measurements for each site were noted. ${ }^{[16,19]}$

The same sonographer who was blinded to the subjects' data performed all the US and sonoelastographic examinations. For intraobserver reliability, measurements were repeated in two sessions with an interval of at least two hours.

The data were analyzed with PASW version 17.0 software (SPSS Inc., Chicago, IL, USA). Descriptive statistics are expressed as mean \pm standard deviation, frequency and percentage. Data of operated and non-operated knees were compared using Wilcoxon test. Percentage of strain ratio difference of operated side to healthy side in comparison with healthy side [(strain ratio of the operated side - strain ratio of the healthy side) / (strain ratio of healthy side) $] \times 100$ was defined as "percentage of strain ratio difference". Spearman's correlation coefficient was used to analyze
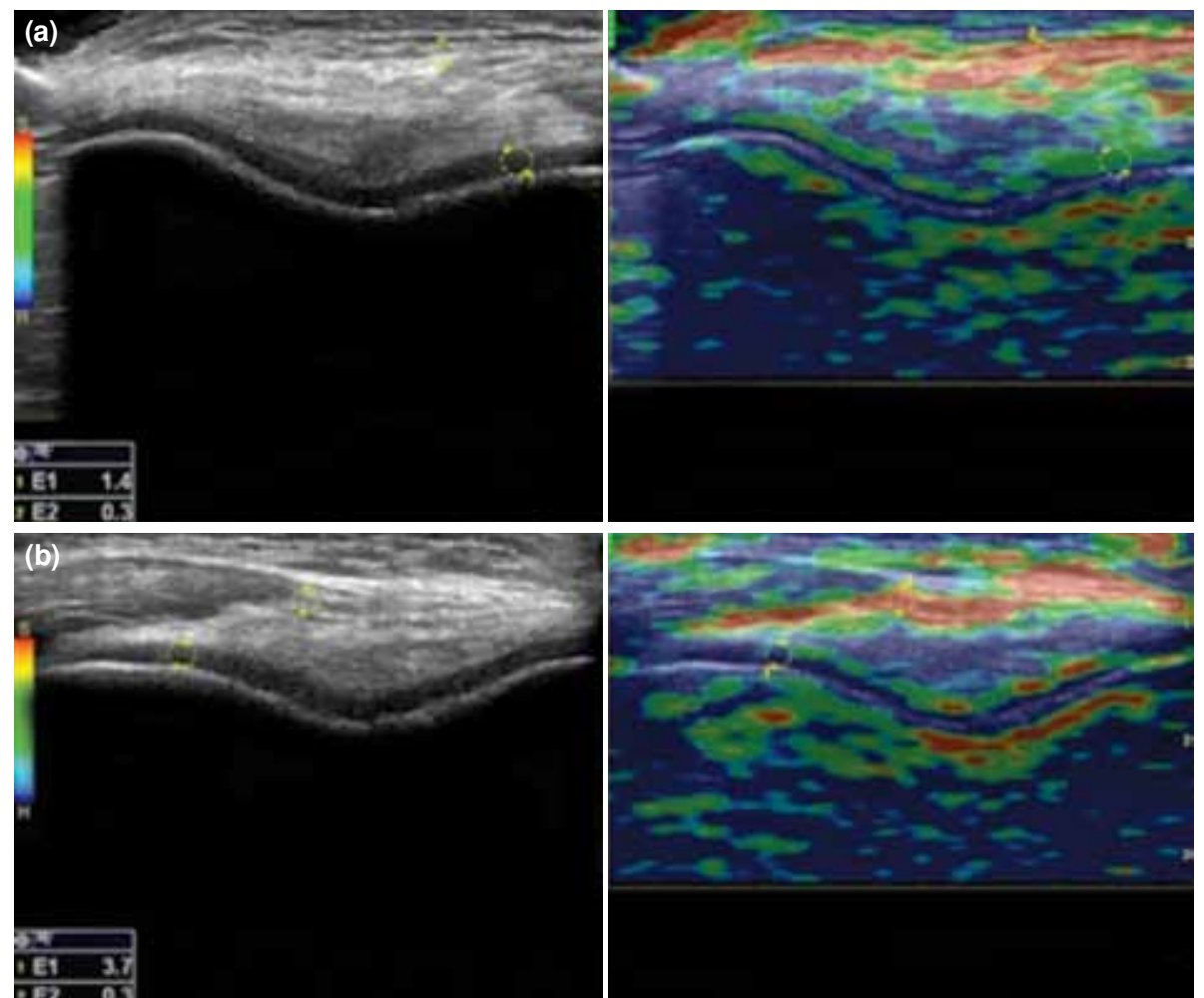

Figure 1. Sonoelastography of a 34-year-old male patient with previous anterior cruciate ligament reconstruction. Elastographic strain ratio is calculated by selection of two regions of interests on real time elastography image. First region of interest is selected on cartilage, and second region of interest is placed on subcutaneous tissue as a reference area. (a) Measurement of strain ratio of medial distal femoral cartilage on operated side. (b) Measurement of strain ratio of medial distal femoral cartilage on non-operated side. 
correlations between percentage of strain ratio difference and other clinical parameters. Statistical significance was set at $\mathrm{p}<0.05$.

\section{RESULTS}

Demographic and clinical characteristics of the subjects are given in Table 1 . There were medial meniscus grade I - II degeneration in $12(42.9 \%)$, lateral meniscus grade I - II degeneration in six (21.4\%), and medial cartilage injury in seven $(25.0 \%)$ patients. None of the patients had received additional procedures like menisectomy, meniscal/cartilage repair or other ligament reconstruction.

Intra-observer reliability was high for both cartilage thickness and strain ratio measurements -intraclass correlation coefficient values for medial, intercondylar and lateral cartilage thickness and strain ratio measurements were $0.994,0.968,0.989$ and $0.981,0.973$ and 0.973 , respectively; all $\mathrm{p}=0.001$ with 95\% confidence interval).

Operated and non-operated knees were similar as regards flexion (135.5 $\pm 1.6,135.6 \pm 1.6$, respectively), extension range of motions $(-0.2 \pm 0.9,0.0 \pm 0.0$, respectively), and pain severity $(0.1 \pm 0.6,0.04 \pm 0.2$, respectively) (all $\mathrm{p}>0.05)$.
Table 2 summarizes the comparative US evaluation results. All cartilage thickness measurements were similar between operated and non-operated knees (all $\mathrm{p}>0.05$ ). While medial and lateral condyle cartilage strain ratio measurements were higher on the operated sides, only those pertaining to the medial compartment reached statistical significance $(\mathrm{p}=0.026)$.

Significantly negative weak correlation was detected between percentage of strain ratio difference of medial distal femoral cartilage and lower limb strength $(\mathrm{p}=0.009, \mathrm{r}=-0.487)$.

\section{DISCUSSION}

The results of this study have shown that strain ratio measurements for the medial femoral cartilage were significantly higher in the operated knees after a mean follow-up period of 20 months. Furthermore, there was a significantly weak negative correlation between percentage of strain ratio difference of operated side medial femoral cartilage and lower body strength.

It has been reported that cartilage degeneration begins at the very early stage with the triggering effect of the pathologic process during ACL injury. ${ }^{[19]}$ It is not obvious whether the risk of cartilage degeneration

TABLE I

Demographic and clinical features of subjects $(n=28)$

\begin{tabular}{|c|c|c|c|c|}
\hline & $\mathrm{n}$ & $\%$ & Mean $\pm S D$ & Range \\
\hline Age (years) & & & $31.7 \pm 7.1$ & $22-48$ \\
\hline Body mass index $\left(\mathrm{kg} / \mathrm{m}^{2}\right)$ & & & $25.9 \pm 2.5$ & $21.5-31$ \\
\hline Preoperative symptom duration (months) & & & $10.8 \pm 18.1$ & $1-84$ \\
\hline Postoperative time (months) & & & $20.4 \pm 9.8$ & $6-60$ \\
\hline Lysholm knee score & & & $88.0 \pm 8.5$ & $66-95$ \\
\hline Lower body strength & & & $20.4 \pm 3.8$ & $12-27$ \\
\hline Satisfaction with operation results & & & $8.2 \pm 1.8$ & 4-10 \\
\hline \multicolumn{5}{|l|}{ Dominant extremity } \\
\hline Right & 22 & 78.6 & & \\
\hline Left & 6 & 21.4 & & \\
\hline \multicolumn{5}{|l|}{ Operated side } \\
\hline Right & 15 & 53.6 & & \\
\hline Left & 13 & 46.4 & & \\
\hline \multicolumn{5}{|l|}{ Graft type } \\
\hline Bone patellar tendon bone & 22 & 78.6 & & \\
\hline Hamstring tendon graft & 6 & 21.4 & & \\
\hline \multicolumn{5}{|l|}{ Presence of any concomitant injury } \\
\hline None & 3 & 10.7 & & \\
\hline Medial meniscal & 12 & 42.9 & & \\
\hline Lateral meniscal & 6 & 21.4 & & \\
\hline Medial cartilage & 7 & 25 & & \\
\hline
\end{tabular}

SD: Standard deviation. 
TABLE II

Comparative ultrasonographic and elastographic measurements $(n=28)$

\begin{tabular}{|c|c|c|c|c|c|}
\hline & \multicolumn{2}{|c|}{ Operated knee } & \multicolumn{2}{|c|}{ Nonoperated knee } & \multirow[b]{2}{*}{$p$} \\
\hline & Mean $\pm S D$ & Min.-Max. & Mean \pm SD & Min.-Max. & \\
\hline Thickness of the medial cartilage (mm) & $2.53 \pm 0.29$ & $1.90-3.10$ & $2.51 \pm 0.25$ & $1.90-2.90$ & 0.731 \\
\hline Thickness of the intercondylar cartilage $(\mathrm{mm})$ & $2.56 \pm 0.31$ & $2.0-3.0$ & $2.58 \pm 0.29$ & $1.80-3.0$ & 0.500 \\
\hline Thickness of the lateral cartilage (mm) & $2.44 \pm 0.32$ & $1.80-2.90$ & $2.44 \pm 0.25$ & 1.9-3.0 & 0.693 \\
\hline Strain ratio of the medial cartilage & $0.23 \pm 0.09$ & $0.1-0.44$ & $0.17 \pm 0.04$ & $0.11-0.30$ & 0.026 \\
\hline Strain ratio of the intercondylar cartilage & $0.21 \pm 0.08$ & $0.11-0.40$ & $0.22 \pm 0.08$ & $0.11-0.44$ & 0.909 \\
\hline Strain ratio of the lateral cartilage & $0.24 \pm 0.09$ & $0.08-0.44$ & $0.19 \pm 0.10$ & $0.07-0.54$ & 0.053 \\
\hline
\end{tabular}

SD: Standard deviation; Min.: Minimum; Max.: Maximum.

is reduced or not with the current ACL reconstruction modalities. ${ }^{[8]}$ Furthermore, Lohmander et al. ${ }^{[20]}$ reported that pathologic mechanisms following ACL injury might be prolonged by the surgical trauma of ACL reconstruction. A strong inflammatory response in synovium that was initiated by trauma was shown through the inflammatory molecules produced by injured and necrotic cells. ${ }^{[21]}$ Heard et al. ${ }^{[21]}$ reported that expression of catabolic and inflammatory molecules following ACL reconstruction in bovines at two weeks were not limited only to the synovium but were also seen in cartilage tissue. These changes persisted up to $20^{\text {th }}$ week with no evidence of repair after reconstruction. It was also reported that cartilage cell death resulted in matrix degradation and glycosaminoglycan loss following trauma, ${ }^{[22]}$ and development of cartilage surface fibrillation was noted in early osteoarthritis. ${ }^{[23]}$ However, following acute posttraumatic phase, subtle metabolic changes of cartilage slowly progress through an asymptomatic clinical period to a symptomatic painful phase with dysfunction. ${ }^{[22]}$ In this study, it was detected that cartilage thickness measurements were similar between operated and non-operated knees while there were strain ratio increase in medial cartilage of operated knees (meaning softer cartilage). However, there is still a need for future studies to assess the relationship between sonoelastographic and histopathologic findings of degenerative changes.

Moreover, it has been reported that joint degeneration following ACL reconstruction ensues due to several causes including changes in joint loading forces, age, BMI, and accompanying ligament or meniscal injuries. Among those, the presence of other ligament and/or meniscal injuries and concomitant menisectomy were considered to be the most influential factors. ${ }^{[6,24]}$ Although concurrent meniscal and/or cartilage injuries were reported at similar rates in the literature, ${ }^{[25]}$ none of our patients had undergone additional operation other than ACL reconstruction. There were no correlations between medial cartilage stain ratio difference of operatedhealthy sides (percentage of strain ratio difference) and age, BMI, and accompanying meniscal/cartilage injuries which have been previously reported as risk factors for OA. Cartilage degeneration might have been triggered by the additional intra-articular conditions during ACL injury in patients of the present study as suggested in previous studies. Therefore, findings of indifferent cartilage thickness measurements in B-mode US evaluations along with significantly different medial distal femoral cartilage strain ratio measurements between operated and non-operated sides may indicate early structural changes in these subjects. However, it is not possible to strongly attribute these changes to the ACL injury since patients with unreconstructed ACL were not evaluated in this study.

One of the reported risk factors for development of radiographic OA after ACL reconstruction is loss of ROM. ${ }^{[26]}$ Since the operated and non-operated knees of subjects in this study were similar in that regard, relevant correlations between loss of $\mathrm{ROM}$ and other parameters could not be analyzed. Herewith, significant negative correlations between the percentages of strain ratio difference of operated side medial cartilage and lower body strength suggest that the better the strength the less would be the cartilage structural changes. Absence of correlations between percentages of strain ratio difference and Lysholm scores may reflect early structural changes without short-term clinical significance.

Small sample size is one of the limitations of our study. Lack of postoperative quantitative evaluation for knee laxity may be considered as another limitation. Although knee laxity was not detected in the postoperative clinical examinations of subjects in this study, studies with objective quantitative evaluations 
may show correlations between the stability level after the reconstruction and the cartilage strain ratio measurements.

In conclusion, in the light of findings of this study, it can be implied that early-/mid-term strain ratio alterations of distal femoral cartilage on operated knees can be detected by US elastography following ACL reconstruction while there was no difference for cartilage thickness. Further histologic studies are needed to uncover whether findings of indifferent cartilage thicknesses along with significantly different medial femoral cartilage strain ratio measurements between operated and healthy knees are early predictors of knee degenerative changes following $\mathrm{ACL}$ reconstruction.

\section{Declaration of conflicting interests}

The authors declared no conflicts of interest with respect to the authorship and/or publication of this article.

\section{Funding}

The authors received no financial support for the research and/or authorship of this article.

\section{REFERENCES}

1. Daniel DM, Stone ML, Dobson BE, Fithian DC, Rossman DJ, Kaufman KR. Fate of the ACL-injured patient. A prospective outcome study. Am J Sports Med 1994;22:632-44.

2. Fetto JF, Marshall JL. The natural history and diagnosis of anterior cruciate ligament insufficiency. Clin Orthop Relat Res 1980;147:29-38.

3. Brandt KD, Myers SL, Burr D, Albrecht M. Osteoarthritic changes in canine articular cartilage, subchondral bone, and synovium fifty-four months after transection of the anterior cruciate ligament. Arthritis Rheum 1991;34:1560-70.

4. Andriacchi TP, Briant PL, Bevill SL, Koo S. Rotational changes at the knee after ACL injury cause cartilage thinning. Clin Orthop Relat Res 2006;442:39-44.

5. Kannus $P$, Järvinen M. Conservatively treated tears of the anterior cruciate ligament. Long-term results. J Bone Joint Surg [Am] 1987;69:1007-12.

6. Ichiba A, Kishimoto I. Effects of articular cartilage and meniscus injuries at the time of surgery on osteoarthritic changes after anterior cruciate ligament reconstruction in patients under 40 years old. Arch Orthop Trauma Surg 2009;129:409-15.

7. Myklebust G, Holm I, Maehlum S, Engebretsen L, Bahr R. Clinical, functional, and radiologic outcome in team handball players 6 to 11 years after anterior cruciate ligament injury: a follow-up study. Am J Sports Med 2003;31:981-9.

8. Atik OŞ. Do we know the optimal management of a torn anterior cruciate ligament of the knee? Eklem Hastalik Cerrahisi 2014;25:63.

9. Atik OŞ. What is the role of the conservative intervention in the treatment of a torn anterior cruciate ligament? Eklem Hastalik Cerrahisi 2015;26:97-9.
10. Wipfler B, Donner S, Zechmann CM, Springer J, Siebold $\mathrm{R}$, Paessler $\mathrm{HH}$. Anterior cruciate ligament reconstruction using patellar tendon versus hamstring tendon: a prospective comparative study with 9-year follow-up. Arthroscopy 2011;27:653-65.

11. Lee CL, Huang MH, Chai CY, Chen CH, Su JY, Tien YC. The validity of in vivo ultrasonographic grading of osteoarthritic femoral condylar cartilage: a comparison with in vitro ultrasonographic and histologic gradings. Osteoarthritis Cartilage 2008;16:352-8.

12. Naredo E, Acebes C, Möller I, Canillas F, de Agustín JJ, de Miguel E, et al. Ultrasound validity in the measurement of knee cartilage thickness. Ann Rheum Dis 2009;68:1322-7.

13. Koo S, Gold GE, Andriacchi TP. Considerations in measuring cartilage thickness using MRI: factors influencing reproducibility and accuracy. Osteoarthritis Cartilage 2005;13:782-9.

14. Klauser AS, Faschingbauer R, Jaschke WR. Is sonoelastography of value in assessing tendons? Semin Musculoskelet Radiol 2010;14:323-33.

15. Tan S, Kudaş S, Özcan AS, İpek A, Karaoğlanoğlu M, Arslan $\mathrm{H}$, et al. Real-time sonoelastography of the Achilles tendon: pattern description in healthy subjects and patients with surgically repaired complete ruptures. Skeletal Radiol 2012;41:1067-72.

16. Cay N, Ipek A, Isik C, Unal O, Kartal MG, Arslan H, et al. Strain ratio measurement of femoral cartilage by realtime elastosonography: preliminary results. Eur Radiol 2015;25:987-93.

17. Tegner Y, Lysholm J. Rating systems in the evaluation of knee ligament injuries. Clin Orthop Relat Res 1985;198:43-9.

18. Laudani L, Giombini A, Mariani PP, Pigozzi F, Macaluso A. Application of the sit-to-stand movement for the early assessment of functional deficits in patients who underwent anterior cruciate ligament reconstruction. Am J Phys Med Rehabil 2014;93:189-99.

19. Li H, Chen S, Tao H, Chen S. Quantitative MRI T2 relaxation time evaluation of knee cartilage: comparison of meniscusintact and -injured knees after anterior cruciate ligament reconstruction. Am J Sports Med 2015;43:865-72.

20. Lohmander LS, Ionescu M, Jugessur H, Poole AR. Changes in joint cartilage aggrecan after knee injury and in osteoarthritis. Arthritis Rheum 1999;42:534-44.

21. Heard BJ, Solbak NM, Achari Y, Chung M, Hart DA, Shrive NG, et al. Changes of early post-traumatic osteoarthritis in an ovine model of simulated ACL reconstruction are associated with transient acute post-injury synovial inflammation and tissue catabolism. Osteoarthritis Cartilage 2013;21:1942-9.

22. Lotz MK, Kraus VB. New developments in osteoarthritis. Posttraumatic osteoarthritis: pathogenesis and pharmacological treatment options. Arthritis Res Ther 2010;12:211.

23. Lee JH, Fitzgerald JB, Dimicco MA, Grodzinsky AJ. Mechanical injury of cartilage explants causes specific time-dependent changes in chondrocyte gene expression. Arthritis Rheum 2005;52:2386-95.

24. Neuman P, Englund M, Kostogiannis I, Fridén T, Roos H, Dahlberg LE. Prevalence of tibiofemoral osteoarthritis 15 years after nonoperative treatment of anterior cruciate ligament injury: a prospective cohort study. Am J Sports 
Med 2008;36:1717-25.

25. Wilder FV, Hall BJ, Barrett JP Jr, Lemrow NB. History of acute knee injury and osteoarthritis of the knee: a prospective epidemiological assessment. The Clearwater Osteoarthritis Study. Osteoarthritis
Cartilage 2002;10:611-6.

26. Shelbourne KD, Freeman H, Gray T. Osteoarthritis after anterior cruciate ligament reconstruction: the importance of regaining and maintaining full range of motion. Sports Health 2012;4:79-85. 